\title{
Chronology of recent sedimentation and geochemical characteristics of sediments in Alvarado Lagoon, Veracruz (southwestern gulf of Mexico)
}

\section{Cronología de la sedimentación reciente y caracterización geoquímica de los sedimentos de la laguna de Alvarado, Veracruz (suroeste del golfo de México)}

\author{
Ana Carolina Ruiz-Fernández ${ }^{*}$, Mohamed Maanan², Joan Albert Sanchez-Cabeza ${ }^{3}$, \\ Libia Hascibe Pérez Bernal ${ }^{1}$, Perla López Mendoza ${ }^{4}$, Audrey Limoges ${ }^{5}$ \\ ${ }^{1}$ Instituto de Ciencias del Mar y Limnología, Universidad Nacional Autónoma de México, Unidad Académica \\ Mazatlán, 82040 Mazatlán, Sinaloa, México. \\ ${ }^{2}$ Université de Nantes, UMR 6554 LETG, BP 81227, 44312, Nantes, France. \\ ${ }^{3}$ Instituto de Ciencias del Mar y Limnología, Universidad Nacional Autónoma de México, Unidad Académica \\ Procesos Oceánicos y Costeros, Ciudad Universitaria, 04510 México DF. \\ ${ }^{4}$ Posgrado en Ciencias del Mar y Limnología, Universidad Nacional Autónoma de México, Unidad Académica \\ Mazatlán, 82040 Mazatlán, Sinaloa, México. \\ ${ }^{5}$ Geotop, Université du Québec à Montréal, CP 8888, succ. Centre-ville, Montréal, Québec, H3C 3P8, Canada.
}

*Corresponding author. E-mail: caro@ola.icmyl.unam.mx

\begin{abstract}
Coastal lagoons are very sensitive to anthropogenic impacts and sedimentary records may provide valuable temporal reconstructions of the environmental changes in the lagoon, the coastal zone, and the catchment area. The Alvarado Lagoon (Veracruz, southwestern gulf of Mexico) belongs to an extensive complex of wetlands recognized as a Ramsar site. However, its catchment basin has one of the highest deforestation rates in Mexico due to the transformation of lowlands for agriculture and grazing, thus causing siltation of the surrounding aquatic bodies. To evaluate the impact of land use change on Alvarado Lagoon, sediment fluxes and provenance were reconstructed by studying the elemental composition (determined by X-ray fluorescence spectrometry) of a sediment core dated radiometrically $\left({ }^{210} \mathrm{~Pb},{ }^{137} \mathrm{Cs},{ }^{239,240} \mathrm{Pu}\right)$. The sedimentary record showed an acceleration of the sediment accumulation rate during more than $134 \pm 17$ years; however, the changes in elemental composition during the past 40 years (i.e., 1972-2011) indicated the incorporation of continental weathered sediments and an increment of sediment accumulation of circa $470 \%$, in coincidence with the period of higher deforestation and siltation. The recent increase in sediment accumulation rates and changes in geochemical features are attributed to erosion caused by land use changes in the Alvarado Lagoon drainage basin.
\end{abstract}

Key words: ${ }^{210} \mathrm{~Pb}$ dating, sediment accumulation rates, Alvarado Lagoon, weathering, land use changes.

RESUMEN. Las lagunas costeras son altamente sensibles a los impactos antrópicos, y los registros sedimentarios pueden proporcionar valiosas reconstrucciones temporales de los cambios ambientales en la laguna, la zona costera y la cuenca de captación. La laguna de Alvarado (Veracruz, suroeste del golfo de México) es parte de un amplio complejo de humedales reconocido como sitio Ramsar. Sin embargo, su cuenca de captación es una de las zonas de México con mayores tasas de deforestación debido a la transformación de tierras bajas en pastizales y terrenos de cultivo, y esto ha repercutido en problemas de azolvamiento en los cuerpos de agua aledaños. Con el propósito de evaluar el impacto del cambio de uso del suelo sobre la laguna de Alvarado, se reconstruyeron los cambios en el flujo y procedencia de los sedimentos por medio del estudio de la composición elemental (determinada por espectrometría de fluorescencia de rayos $\mathrm{X}$ ) de un núcleo sedimentario fechado por métodos radiométricos $\left({ }^{210} \mathrm{~Pb},{ }^{137} \mathrm{Cs},{ }^{239,240} \mathrm{Pu}\right)$. El registro sedimentario mostró evidencia del aceleramiento del ritmo de sedimentación desde hace más de $134 \pm 17$ años; sin embargo, durante los últimos 40 años (1972-2011) se observaron cambios en la composición elemental que señalan la incorporación de sedimentos intemperizados de origen continental, así como un incremento de alrededor del $470 \%$ en las tasas de acumulación sedimentaria, que coinciden con los periodos de mayor deforestación y azolvamiento. Los incrementos recientes en las tasas de acumulación y el cambio en las características geoquímicas se atribuyeron a la erosión causada por cambios de uso del suelo en la cuenca de drenaje de la laguna de Alvarado.

Palabras clave: fechado con ${ }^{210} \mathrm{~Pb}$, tasas de acumulación sedimentaria, laguna de Alvarado, intemperismo, cambio de uso del suelo.

\section{INTRODUCTION}

Global change refers to changes in the structure and functioning of the Earth System, caused by the rapid increase in human population. Among its most conspicuous

\section{INTRODUCCIÓN}

El término cambio global hace referencia a los cambios en la estructura y funcionamiento del sistema Tierra ocasionados por el rápido crecimiento de la población 
effects is the increased erosion due to land-use changes (Vitousek 1994, Ruiz-Fernández et al. 2014) and to the loss of vegetation cover associated with the growing human demand for natural resources. Coastal areas, the natural interface between river basins and oceans, and home to a quarter of the global population (Nicholls and Small 2002), are particularly valuable ecosystems and include some of the ecosystems that are most strongly impacted by global change.

Land-use changes can be recognized in sedimentary records of coastal ecosystems because they generally increase soil erosion, which is reflected in increased sediment accumulation rates in aquatic systems (e.g., Ruiz-Fernández et al. 2009) and in the geochemical composition of sediments (e.g., Koinig et al. 2003, Ruiz-Fernández et al. 2012). To evaluate changes in sedimentation rates and identify the factors controlling them, a reliable time frame is required.

The most widely used method to reconstruct recent environmental changes in aquatic systems is ${ }^{210} \mathrm{~Pb}$ dating. ${ }^{210} \mathrm{~Pb}$ is a natural radionuclide, a member of the ${ }^{238} \mathrm{U}$ radioactive series. It has a half-life $\left(T_{1 / 2}\right)$ of 22.23 years and can be used to date sediments deposited over the last 100-150 years, period during which the diverse effects of climate change are more noticeable (e.g., pollution, sea level rise, eutrophication).

The fluvio-lagoon, deltaic-estuarine Alvarado complex is important in terms of ecological and economic (fisheries, tourism) value. It is surrounded by the second largest mangrove forest in Veracruz State (Mexico). It is considered a priority area for land, marine, and hydrological protection, and for bird conservation by the National Commission for the Knowledge and Use of Biodiversity (CONABIO, Mexico), and has been recognized as a Ramsar site since 2004. Nonetheless, impacts to the ecosystem have been documented, including, among others, pollution from urban, agricultural, and industrial wastes; the modification of its environment due to the felling of mangrove trees; the conversion of extensive forest areas to pasture lands; and an increase in erosion and sediment transport (DOF 2004).

Under the premise that erosion of the drainage basin has modified the sediment quality and accumulation rate in the Alvarado Lagoon System, we have quantitatively reconstructed the changes in sediment accumulation rate ( $\left.\mathrm{cm} \mathrm{yr}^{-1}\right)$ and mass accumulation rate $\left(\mathrm{g} \mathrm{cm}^{-2} \mathrm{yr}^{-1}\right)$ during the last $134 \pm 17$ years in a sediment core from Alvarado Lagoon. The sediments were dated with the ${ }^{210} \mathrm{~Pb}$ method and the chronology was corroborated with the radioactive tracers ${ }^{137} \mathrm{Cs}$ and ${ }^{239,240} \mathrm{Pu}$. The textural and geochemical characteristics of the sediments were used to evaluate the degree of chemical weathering and determine the changes in sediment provenance, which were related to changes in land use and deforestation in the area. humana. Entre sus manifestaciones más conspicuas, está el aumento de la erosión debido a cambios de uso del suelo (Vitousek 1994, Ruiz-Fernández et al. 2014) y a la pérdida de cobertura vegetal, relacionada con la demanda de recursos naturales para satisfacer las necesidades de la población. Las zonas costeras, interfase natural entre las cuencas y los océanos, son ecosistemas especialmente valiosos e incluyen algunos de los ecosistemas más impactados por el cambio global, debido a que albergan una cuarta parte de la población mundial (Nicholls y Small 2002).

Los cambios en el uso del suelo pueden ser reconocidos en los registros sedimentarios de los ecosistemas costeros debido a que generalmente aumentan la erosividad del suelo, lo cual se ve reflejado en aumentos del ritmo de acumulación sedimentaria en los sistemas acuáticos (e.g., Ruiz-Fernández et al. 2009) y en cambios en la composición geoquímica de los sedimentos (e.g., Koinig et al. 2003, Ruiz-Fernández et al. 2012). Para evaluar los cambios en las tasas de sedimentación e identificar los factores que los controlan, se requiere de un marco temporal confiable.

El método de fechado con ${ }^{210} \mathrm{~Pb}$ es el más utilizado para reconstruir los cambios ambientales recientes en sistemas acuáticos. El ${ }^{210} \mathrm{~Pb}$ es un radionúclido natural, miembro de la serie radiactiva del ${ }^{238} \mathrm{U}$; tiene un periodo de semidesintegración $\left(T_{1 / 2}\right)$ de 22.23 años y permite fechar sedimentos acumulados en los últimos 100-150 años, periodo durante el cual son más notables las diversas manifestaciones del cambio global (e.g., contaminación, elevación del nivel del mar, eutrofización).

El complejo fluvio-lagunar y deltáico-estuarino de Alvarado es un sistema de gran importancia ecológica, pesquera y turística. Se encuentra rodeado por la segunda área de mayor superficie de manglar en el estado de Veracruz (México). Es considerado una región prioritaria para la conservación terrestre, marina e hidrológica, y para la conservación de las aves por parte de la Comisión Nacional de Biodiversidad (CONABIO), $\mathrm{y}$ ha sido declarado sitio RAMSAR desde 2004. No obstante, se han registrado diversos impactos al ecosistema, tales como la contaminación por residuos urbanos, agrícolas e industriales; la modificación de su entorno debido a la tala de manglar; la conversión de extensas áreas forestales a terrenos ganaderos; y el incremento de la erosión y acarreo de sedimentos (DOF 2004).

Bajo la premisa de que la erosión de la cuenca de drenaje ha modificado el ritmo de sedimentación y la calidad del sedimento acumulado en la laguna de Alvarado, en este trabajo hemos reconstruido cuantitativamente los cambios en las tasas de acumulación sedimentaria $\left(\mathrm{cm} \mathrm{año}^{-1}\right)$ y másica $\left(\mathrm{g} \mathrm{cm}^{-2}\right.$ año $\left.{ }^{-1}\right)$ durante $134 \pm 17$ años registrados en un núcleo sedimentario recolectado en la laguna de Alvarado. Los sedimentos fueron fechados con el método de ${ }^{210} \mathrm{~Pb}$ y la cronología fue corroborada con los trazadores radioactivos ${ }^{137} \mathrm{Cs}$ y ${ }^{239,240} \mathrm{Pu}$. Se utilizaron las características texturales y geoquímicas de los sedimentos para evaluar el grado de intemperismo químico en los sedimentos y evidenciar los cambios en 


\section{MATERIALS AND METHODS}

\section{Study area}

Alvarado Lagoon is located on the coast of central Veracruz State (SW Gulf of Mexico). It forms part of the Alvarado Lagoon System (8637.5 ha, fig. 1), which consists of four interconnected brackish, shallow (3 m maximum depth) coastal lagoons: Alvarado (4452.5 ha), Buen País (512.5 ha), Camaronera (2212.5 ha), and Tlalixcoyan (1460 ha). More than 100 inner lagoons and the Papaloapan, Acula, Blanco, and Limón rivers also form part of the system (Contreras-Espinosa 1993, Portilla-Ochoa 2003).

The climate of the region is type Aw2 (warm subhumid), with mean annual temperature higher than $22^{\circ} \mathrm{C}$, temperature of the coldest month higher than $18{ }^{\circ} \mathrm{C}$, and mean annual rainfall of 500 to $2500 \mathrm{~mm}$ (Arriaga et al. 2000). The dominant soils of the region are Gleysols (38\%), Vertisols (24\%), Arenosols (15\%), and Solonchaks (2\%) (INEGI 2009).

The Alvarado Lagoon System is a highly productive ecosystem. It contains extensive mangrove forests (red mangrove, Rhizophora mangle; white mangrove, Laguncularia racemosa; and black mangrove, Avicennia germinans), it is inhabited by the manatee Trichechus manatus (in danger of extinction), and it is a refuge for endangered and threatened bird species (CONAMP 2014). Previous studies have reported problems of siltation in the estuarine system due to soil erosion caused by deforestation in the upper part of the basin (Bello et al. 2009) and heavy metal contamination (e.g., $\mathrm{Cu}, \mathrm{Ni}, \mathrm{Pb}$, and $\mathrm{Zn}$ ) in sediments (Rosales et al. 1986, Guzmán-Amaya et al. 2005).

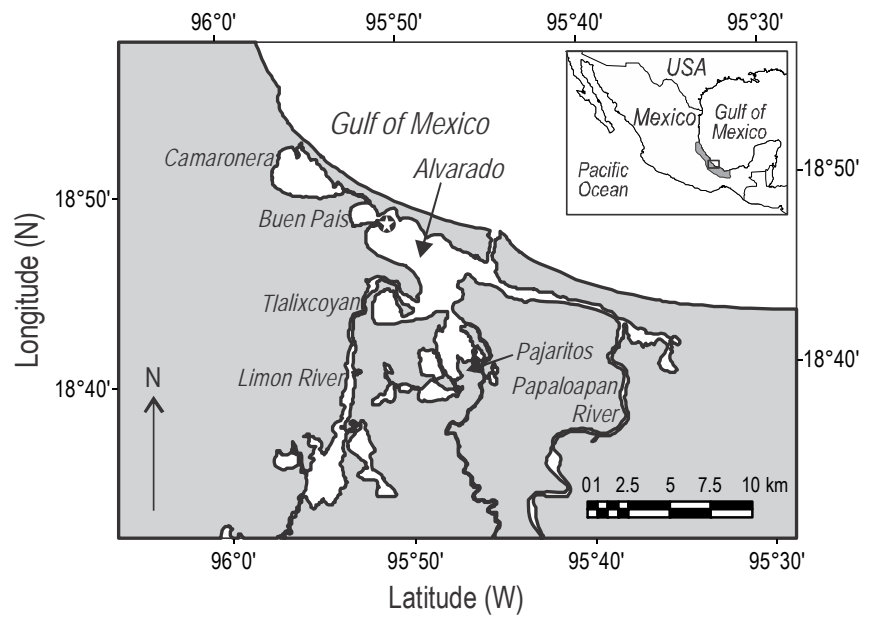

Figure 1. Study area in the Alvarado Lagoon System, Veracruz, SW Gulf of Mexico. The star indicates the sediment core collection site in Alvarado Lagoon.

Figura 1. Área de estudio en el complejo lagunar de Alvarado, Veracruz, suroeste del golfo de México. La estrella indica el sitio de recolección (laguna de Alvarado) del núcleo sedimentario. la procedencia de los sedimentos, que fueron relacionados con cambios de uso del suelo y deforestación en la zona.

\section{MATERIALES Y MÉTODOS}

\section{Área de estudio}

La laguna de Alvarado se localiza en la zona centro del estado de Veracruz (SW del golfo de México). Forma parte del complejo lagunar de Alvarado (8637.5 ha, fig. 1), conformado por cuatro lagunas costeras salobres y someras $(3 \mathrm{~m}$ máximo) interconectadas: Alvarado (4452.5 ha), Buen País (512.5 ha), Camaronera (2212.5 ha) y Tlalixcoyan (1460 ha). El complejo lagunar también incluye más de 100 lagunas interiores y los ríos Papaloapan, Acula, Blanco y Limón (Contreras-Espinosa 1993, Portilla-Ochoa 2003).

El clima en la zona es de tipo Aw2, cálido subhúmedo con temperatura media anual mayor que $22^{\circ} \mathrm{C}$, temperatura del mes más frío mayor que $18^{\circ} \mathrm{C}$ y precipitación media anual de 500 a $2500 \mathrm{~mm}$ (Arriaga et al. 2000). Los suelos dominantes de la región son de tipo Gleysol (38\%), Vertisol (24\%), Arenosol (15\%) y Solonchak (2\%) (INEGI 2009).

El complejo lagunar de Alvarado es un ecosistema altamente productivo: alberga extensos bosques de mangle (mangle rojo, Rhizophora mangle; mangle blanco, Laguncularia racemosa; y mangle negro, Avicennia germinans), es hábitat del manatí Trichechus manatus (en peligro de extinción) y es refugio de especies de aves consideradas en peligro o amenazadas (CONAMP 2014). Estudios previos han registrado problemas de azolvamiento del sistema estuarino debido a la erosión de suelos causada por la deforestación en la parte alta de la cuenca (Bello et al. 2009) y contaminación de los sedimentos por metales pesados (e.g., $\mathrm{Cu}, \mathrm{Ni}, \mathrm{Pb}$ y $\mathrm{Zn}$; Rosales et al. 1986, Guzmán Amaya et al. 2005).

\section{Muestreo}

El núcleo sedimentario Alvarado se recolectó en noviembre de 2011 en la laguna de Alvarado (18 47'52.44" N, 95 $51^{\prime} 28.44^{\prime \prime} \mathrm{W}$; fig. 1), a $1.5 \mathrm{~m}$ de profundidad de columna del agua. Se utilizó un nucleador de gravedad (UWITEC) provisto de un tubo de PVC transparente de $1 \mathrm{~m}$ de largo y $8.5 \mathrm{~cm}$ de diámetro interno. El núcleo fue extrudido y seccionado en intervalos de $1 \mathrm{~cm}$ de espesor. Las muestras se pesaron, congelaron y secaron con una liofilizadora Labconco (modelo 7754042). Se registró el peso seco para determinar la densidad in situ y la profundidad másica de acuerdo con Sanchez-Cabeza y Ruiz-Fernández (2012). Las muestras fueron molidas en mortero de porcelana y almacenadas en bolsas de plástico hasta su análisis.

\section{Análisis de laboratorio}

\section{Radiocronología con ${ }^{210} \mathrm{~Pb}$}

$\mathrm{El}{ }^{210} \mathrm{~Pb}$ en los sedimentos $\left({ }^{210} \mathrm{~Pb}\right.$ total $)$ incluye una fracción que procede principalmente de la atmósfera $\left({ }^{210} \mathrm{~Pb}_{\text {exceso }}\right)$, 


\section{Sampling}

The sediment core was collected from Alvarado Lagoon (18 $47^{\prime} 52.44^{\prime \prime} \mathrm{N}, 95^{\circ} 51^{\prime} 28.44^{\prime \prime} \mathrm{W}$; fig. 1) in November 2011, at a water depth of $1.5 \mathrm{~m}$. Sampling was performed using an UWITEC gravity corer with a transparent PVC liner $(1 \mathrm{~m}$ long, $8.5 \mathrm{~cm}$ inner diameter). The core was extruded and sectioned to obtain 1-cm-thick slices. The samples were weighed, frozen, and dried in a Labconco 7754042 freeze dryer. The dry weight was recorded to determine the in situ density and mass depth according to Sanchez-Cabeza and Ruiz-Fernández (2012). The samples were ground in a porcelain mortar and stored in plastic bags until their analysis.

\section{Laboratory analysis}

\section{${ }^{210} \mathrm{~Pb}$ radiochronology}

The ${ }^{210} \mathrm{~Pb}$ in the sediments $\left({ }^{210} \mathrm{~Pb}_{\text {total }}\right)$ includes a fraction that originates from the atmosphere $\left({ }^{210} \mathrm{~Pb}\right.$ excess $)$, where ${ }^{210} \mathrm{~Pb}$ forms due to the decay of ${ }^{222} \mathrm{Rn}$ gas emanating from the soil into the air, and a fraction produced in situ $\left({ }^{210} \mathrm{~Pb}_{\text {supported }}\right)$ that can be determined as the average of the ${ }^{210} \mathrm{~Pb}_{\text {total }}$ values in the asymptotic section of the ${ }^{210} \mathrm{~Pb}_{\text {total }}$ activity profile relative to depth (fig. 2a). The activity of ${ }^{210} \mathrm{~Pb}_{\text {excess }}$ is used to date the sediments and is calculated as the difference between ${ }^{210} \mathrm{~Pb}_{\text {total }}$ and ${ }^{210} \mathrm{~Pb}_{\text {supported }}$ (Sanchez-Cabeza et al. 2012).

The activity of ${ }^{210} \mathrm{~Pb}_{\text {total }}$ was determined from the activity of its descendant ${ }^{210} \mathrm{Po}$ measured by alpha spectrometry, assuming secular equilibrium between both isotopes, as described by Ruiz-Fernández et al. (2009). Briefly, a known amount of ${ }^{209} \mathrm{Po}$ was added as an internal standard to a $0.3-\mathrm{g}$ aliquot of dried, ground sediment, which was digested in Teflon containers (Savillex) on a hot plate at $120^{\circ} \mathrm{C}$ for $12 \mathrm{~h}$ using a 5:4:1 mixture of concentrated $\mathrm{HNO}_{3}: \mathrm{HCl}: \mathrm{HF}$. The digest was evaporated to dryness $\left(<80^{\circ} \mathrm{C}\right)$ and the residue was suspended in concentrated $\mathrm{HCl}$ to eliminate the remnants of $\mathrm{HNO}_{3}$ (this step was repeated three times). The final residue was resuspended in $0.5 \mathrm{~N} \mathrm{HCl}$ and eliminated by centrifugation; $0.5 \mathrm{~g}$ of ascorbic acid was added to the supernatant in which a silver disc $(2 \mathrm{~cm}$ diameter $)$ was introduced (12 h, orbital agitation, room temperature) to allow the spontaneous deposition of the polonium isotopes. The activity of ${ }^{209} \mathrm{Po}$ and ${ }^{210} \mathrm{Po}$ was measured in an Ortec 576A alpha spectrometer until the counting uncertainty was less than $5 \%$. The analysis of replicates $(n=4)$ of the certified reference material IAEA-300 (radionuclides in Baltic Sea sediment) confirmed the accuracy and precision of the method (within $1 \sigma$ of the certified value of ${ }^{210} \mathrm{~Pb}$ and with a coefficient of variation of $3.5 \%$, respectively).

The sediment chronology was established using the constant flux model (Robbins 1978, Sanchez-Cabeza and Ruiz-Fernández 2012). The fundamental premise of the model is that the flux of ${ }^{210} \mathrm{~Pb}$ to the sediment surface is donde el ${ }^{210} \mathrm{~Pb}$ se forma debido a la desintegración del gas ${ }^{222} \mathrm{Rn}$ que emana de los suelos, y una fracción producida in situ $\left({ }^{210} \mathrm{~Pb}_{\text {soportado }}\right)$ que puede determinarse como el promedio de los valores de ${ }^{210} \mathrm{~Pb}_{\text {total }}$ en la sección asintótica del perfil de actividad de ${ }^{210} \mathrm{~Pb}_{\text {total }}$ respecto a la profundidad (fig $2 \mathrm{a}$ ). $\mathrm{La}$ actividad de ${ }^{210} \mathrm{~Pb}_{\text {exceso }}$ se utiliza para el fechado de los sedimentos y se calcula como la diferencia entre ${ }^{210} \mathrm{~Pb}_{\text {total }} \mathrm{y}$ ${ }^{210} \mathrm{~Pb}_{\text {soportado }}$ (Sanchez-Cabeza et al. 2012).

La actividad de ${ }^{210} \mathrm{~Pb}_{\text {total }}$ se determinó a través de la actividad de su descendiente ${ }^{210} \mathrm{Po}$ medida mediante espectrometría alfa, bajo la suposición de equilibrio secular entre ambos isótopos, en conformidad con el método descrito por RuizFernández et al. (2009). Brevemente, se agregó una cantidad conocida de ${ }^{209} \mathrm{Po}$ como estándar interno a una alícuota de $0.3 \mathrm{~g}$ de sedimento seco y molido, la cual se digirió en una mezcla de ácidos concentrados (5:4:1 de $\mathrm{HNO}_{3}$-HCl-HF) en recipientes de teflón (Savillex) sobre una plancha de calentamiento a $120^{\circ} \mathrm{C}$ durante $12 \mathrm{~h}$. El digerido se evaporó a sequedad $\left(<80^{\circ} \mathrm{C}\right)$ y el residuo se suspendió en $\mathrm{HCl}$ concentrado para eliminar los remanentes de $\mathrm{HNO}_{3}$ (este paso se repitió tres veces). El residuo final se resuspendió en $\mathrm{HCl} 0.5 \mathrm{~N}$ y se eliminó por centrifugación; se agregaron $0.5 \mathrm{~g}$ de ácido ascórbico al sobrenadante y se puso en contacto con un disco de plata ( $2 \mathrm{~cm}$ de diámetro) para permitir el depósito espontáneo de los isótopos de polonio mediante agitación orbital durante $12 \mathrm{~h}$ a temperatura ambiente. La actividad de ${ }^{209} \mathrm{Po}$ y ${ }^{210}$ Po se midió en un espectrómetro alfa Ortec 576A durante el tiempo necesario para obtener una incertidumbre de conteo menor que el $5 \%$. El análisis de réplicas $(n=4)$ del material de referencia certificado IAEA-300 (radionúclidos en sedimento del mar Báltico) confirmó una buena exactitud y precisión del método (dentro de $1 \sigma$ del valor certificado de ${ }^{210} \mathrm{~Pb}$ y con un coeficiente de variación del 3.5\%, respectivamente).

Para establecer la cronología de los sedimentos, se utilizó el modelo de flujo constante (Robbins 1978, Sanchez-Cabeza y Ruiz-Fernández 2012). La hipótesis fundamental del modelo es que el flujo de ${ }^{210} \mathrm{~Pb}$ a la superficie del sedimento es constante; por lo tanto, la actividad de ${ }^{210} \mathrm{~Pb}$ en los sedimentos es resultado de su desintegración radioactiva y de los cambios en el ritmo de acumulación de los sedimentos (Sanchez-Cabeza y Ruiz-Fernández 2012). La incertidumbre de la cronología y la acumulación sedimentaria fue calculada mediante un método de simulación Monte Carlo (SanchezCabeza et al. 2014).

\section{Marcadores estratigráficos}

El fechado con ${ }^{210} \mathrm{~Pb}$ se corroboró con los perfiles de distribución de los marcadores estratigráficos ${ }^{137} \mathrm{Cs}\left(\mathrm{T}_{1 / 2}=\right.$ 30.14 años) y ${ }^{239,240} \mathrm{Pu}\left({ }^{239} \mathrm{Pu}, \mathrm{T}_{1 / 2}=24,100\right.$ años; ${ }^{240} \mathrm{Pu}, \mathrm{T}_{1 / 2}=$ 6561 años). ${ }^{137} \mathrm{Cs}$ y ${ }^{239,240} \mathrm{Pu}$ son radionúclidos artificiales que se encuentran presentes en el ambiente principalmente debido a la precipitación global, resultado de las pruebas atmosféricas de armamento termonuclear. ${ }^{137} \mathrm{Cs}$ y ${ }^{239,240} \mathrm{Pu}$ 
constant; hence, the activity of ${ }^{210} \mathrm{~Pb}$ in sediments is the result of its radioactive decay and of changes in the rhythm of sediment accumulation (Sanchez-Cabeza and Ruiz-Fernández 2012). The uncertainty of the sediment chronology and accumulation was calculated by a Monte Carlo method (Sanchez-Cabeza et al. 2014).

\section{Stratigraphic markers}

The ${ }^{210} \mathrm{~Pb}$ dating was corroborated with the distribution profiles of the stratigraphic markers ${ }^{137} \mathrm{Cs}\left(\mathrm{T}_{1 / 2}=30.14 \mathrm{yr}\right)$ and ${ }^{239,240} \mathrm{Pu}\left({ }^{239} \mathrm{Pu}, \mathrm{T}_{1 / 2}=24,100 \mathrm{yr} ;{ }^{240} \mathrm{Pu}, \mathrm{T}_{1 / 2}=6561 \mathrm{yr}\right) .{ }^{137} \mathrm{Cs}$ and ${ }^{239,240} \mathrm{Pu}$ are artificial radionuclides that are present in the environment due to global fallout from the testing of thermonuclear weapons. ${ }^{137} \mathrm{Cs}$ and ${ }^{239,240} \mathrm{Pu}$ are detectable in sediments after the first thermonuclear tests were conducted in the early 1950s and present maximum activity between 1962 and 1964, after which their activity decreases (DeLaune et al. 1978).

The activity of ${ }^{137} \mathrm{Cs}$ was determined by high-resolution gamma spectrometry. Dried, ground sediment aliquots $(\sim 4.5 \mathrm{~g})$, contained in plastic vials $(6 \mathrm{~cm}$ long $\times 1 \mathrm{~cm}$ diameter), were analyzed for a minimum of $48 \mathrm{~h}$, using an Ortec hyper-pure Ge detector.

The activity of ${ }^{239,240} \mathrm{Pu}$ was determined by alpha spectrometry using Ortec-Ametek 576A systems. Approximately $3 \mathrm{~g}$ of calcined sediment $\left(600^{\circ} \mathrm{C}\right.$ for $\left.8 \mathrm{~h}\right)$, added with a known amount of ${ }^{242} \mathrm{Pu}$ standard as recovery tracer, was digested in a mixture of concentrated acids $(1: 3 \mathrm{HCl}+$ $\left.\mathrm{HNO}_{3}\right)$ on a hot plate $\left(150{ }^{\circ} \mathrm{C}, 6 \mathrm{~h}\right)$. The plutonium isotopes were purified using anion exchange resin (AG $1 \times 8-200$, Bio-Rad Laboratories, Inc.; Wong 1971) and electrodeposited on a silver disc $(0.3 \mathrm{~mm}$ thick, $2 \mathrm{~cm}$ diameter; Puphal and Olsen 1972), using an electrolyte solution consisting of a mixture of $\mathrm{HCl}$ and ammonium oxalate + ammonium chloride $(\mathrm{pH}=2)$, a platinum anode ( $1 \mathrm{~mm}$ thick $)$, and an Agilent U8001A power supply (1 A current).

\section{Geochemical characterization of sediments}

The grain-size distribution of the sediments was determined using a Malvern Masterizer 2000. Before the analysis, the samples were treated with $30 \% \mathrm{H}_{2} \mathrm{O}_{2}$ to remove organic matter. Organic matter content was determined by the Walkley-Black method described by Loring and Rantala (1992), and the concentration of carbonates $\left(\mathrm{CaCO}_{3}\right)$ was analyzed by the volumetric method described by Stuardo and Villarroel (1976). The magnetic susceptibility of the sediments was determined on dried, ground sediment, using a Bartington MS2 magnetic susceptibility meter coupled to a MSG2 frequency sensor. The elemental composition of the sediments $(13<Z<92)$ was determined by $X$-ray fluorescence (Spectro Xepos-3): $4 \mathrm{~g}$ of ground sediment were suelen ser detectables en los sedimentos después de las primeras pruebas termonucleares a principios de la década de 1950, y presentar actividades máximas entre 1962 y 1964, y una reducción a partir de entonces (DeLaune et al. 1978).

La actividad de ${ }^{137} \mathrm{Cs}$ se determinó mediante espectrometría gamma de alta resolución. Se analizaron alícuotas de sedimento seco y molido ( $\sim 4.5 \mathrm{~g})$, contenidas en viales de plástico $(6 \mathrm{~cm}$ de largo $\times 1 \mathrm{~cm}$ de diámetro), durante un mínimo de $48 \mathrm{~h}$, en un detector de pozo de Ge hiperpuro (Ortec).

La actividad de ${ }^{239,240} \mathrm{Pu}$ se determinó mediante espectrometría alfa en sistemas Ortec-Ametek 576A. Aproximadamente $3 \mathrm{~g}$ de sedimento calcinado $\left(600{ }^{\circ} \mathrm{C}\right.$ por $\left.8 \mathrm{~h}\right)$, adicionados con un estándar de ${ }^{242} \mathrm{Pu}$ como trazador de recuperación, se digirieron en una mezcla de ácidos concentrados $\left(1: 3 \mathrm{HCl}+\mathrm{HNO}_{3}\right)$ en una plancha de calentamiento $\left(150^{\circ} \mathrm{C}\right.$, $6 \mathrm{~h})$. Los isótopos de plutonio fueron purificados con una resina de intercambio aniónico (AG $1 \times 8-200$, Bio-Rad Laboratories, Inc.; Wong 1971) y se electrodepositaron sobre un disco de plata $(0.3 \mathrm{~mm}$ de espesor, $2 \mathrm{~cm}$ de diámetro; Puphal y Olsen 1972) utilizando como solución electrolito una mezcla de $\mathrm{HCl}$ y oxalato de amonio + cloruro de amonio $(\mathrm{pH}=2)$, un ánodo de platino ( $1 \mathrm{~mm}$ de espesor) y una fuente de poder Agilent U8001A (corriente de $1 \mathrm{~A}$ ).

\section{Caracterización geoquímica de los sedimentos}

La distribución del tamaño de grano de los sedimentos se determinó con un equipo de difracción de rayo láser Malvern Masterizer 2000. Previo al análisis, las muestras se trataron con $\mathrm{H}_{2} \mathrm{O}_{2}$ al $30 \%$ para eliminar la materia orgánica. Para determinar la concentración de materia orgánica, se utilizó el método de Walkley-Black descrito por Loring y Rantala (1992), y la concentración de carbonatos (como $\mathrm{CaCO}_{3}$ ) se analizó utilizando el método volumétrico descrito por Stuardo y Villarroel (1976). La susceptibilidad magnética de los sedimentos se determinó en sedimento seco y molido, utilizando un medidor de susceptibilidad magnética Bartington MS2 acoplado a un sensor de frecuencia simple MSG2. La composición elemental de los sedimentos $(13<Z<92)$ se determinó por fluorescencia de rayos $X$ (Spectro Xepos-3): $4 \mathrm{~g}$ de sedimento molido fueron colocados en una celda de polietileno de baja densidad con fondo recubierto con una película de Prolene.

\section{Análisis estadísticos}

Se realizó un análisis de correlación de Pearson para determinar la asociación entre las variables analizadas, y se determinó la significancia del coeficiente de correlación mediante una prueba de $t$ de Student $(P<0.01)$. Previo al análisis se verificó que los datos tuvieran una distribución normal mediante la prueba de Kolmogorov-Smirnov. 
placed in a low-density polyethylene cell with the bottom covered with Prolene film.

\section{Statistical analysis}

A Pearson correlation analysis was performed to determine the association among the analyzed variables, and the significance of the correlation coefficient was determined by the Student's $t$-test $(P<0.01)$. Before the analysis, the Kolmogorov-Smirnov test was used to verify the normal distribution of the data.

\section{RESUlts}

\section{Time frame}

${ }^{210} \mathrm{~Pb}$ dating

The activity of ${ }^{210} \mathrm{~Pb}_{\text {total }}$ in the Alvarado sediment core ranged from 18.5 to $76.0 \mathrm{~Bq} \mathrm{~kg}{ }^{-1}$. The value of ${ }^{210} \mathrm{~Pb}_{\text {supported, }}$, estimated based on the average activity of ${ }^{210} \mathrm{~Pb}_{\text {total }}$ between 23 and $57 \mathrm{~cm}$ depth, was $21.3 \pm 1.8 \mathrm{~Bq} \mathrm{~kg}^{-1}$ (fig. 2a). A maximum age of $134 \pm 17$ years (i.e., 1878, $19-20 \mathrm{~cm}$ section) was estimated with the dating method. The age model and the variation of the mass accumulation rate $\left(0.04-0.23 \mathrm{~g} \mathrm{~cm}^{-2} \mathrm{yr}^{-1}\right)$ and sediment accumulation rate $\left(0.06-0.61 \mathrm{~cm} \mathrm{yr}^{-1}\right)$ are presented in figure $2 \mathrm{c}$.

Validation with ${ }^{137} \mathrm{Cs}$ and ${ }^{239,240} \mathrm{Pu}$

The activities of ${ }^{137} \mathrm{Cs}$ and ${ }^{239,240} \mathrm{Pu}$ in the Alvarado sediment core ranged from 1.2 to $4.6 \mathrm{~Bq} \mathrm{~kg}^{-1}$ and from 72 to $182 \mathrm{mBq} \mathrm{kg}^{-1}$, respectively. The ${ }^{137} \mathrm{Cs}$ and ${ }^{239,240} \mathrm{Pu}$ activity profiles (fig. 2b) show maximum values in the $11-12 \mathrm{~cm} \mathrm{sec-}$ tion, which according to the age model corresponds to the years from 1958 to 1966, in perfect agreement with the expected maximum activity in 1963.

\section{Characterization of the sediments}

The sediments were mainly silty (69-90\%), with low organic matter $(<2 \%)$ and carbonate $(1-7 \%)$ content. Most of the variables analyzed showed little variation relative to depth (fig. 3, note the reduced amplitude of the scales), although the in situ density $(\rho)$ of the sediments, the sand content, and the magnetic susceptibility values were slightly lower in the lower segment (below $26 \mathrm{~cm}$ depth) than towards the surface of the core.

The carbonate and $\mathrm{Ca}$ concentrations showed a constant decreasing trend from the bottom to the surface of the core. The magnetic susceptibility values showed a maximum between 19 and $28 \mathrm{~cm}$ depth (older than AD $1878 \pm 17$ ), coinciding with the maximum percentages of sand, $\mathrm{Ca}$, and $\mathrm{Zr}$, and minimum percentages of silt and $\mathrm{Rb}$. The concentrations of $\mathrm{Al}, \mathrm{K}, \mathrm{Rb}, \mathrm{Si}$, and $\mathrm{Fe}$ showed a decreasing trend

\section{RESUltados}

\section{Marco temporal de los sedimentos}

\section{Fechado con el método de ${ }^{210} \mathrm{~Pb}$}

La actividad de ${ }^{210} \mathrm{~Pb}_{\text {total }}$ en los sedimentos del núcleo Alvarado varió de 18.5 a $76.0 \mathrm{~Bq} \mathrm{~kg}{ }^{-1}$. El valor de ${ }^{210} \mathrm{~Pb}_{\text {soportado }}$, estimado a partir del promedio de las actividades de ${ }^{210} \mathrm{~Pb}_{\text {total }}$ entre 23 y $57 \mathrm{~cm}$ de profundidad, fue de $21.3 \pm 1.8 \mathrm{~Bq} \mathrm{~kg}^{-1}$ (fig. 2a). El método de fechado permitió estimar una edad máxima de $134 \pm 17$ años (i.e., 1878, sección $19-20 \mathrm{~cm})$. El modelo de edad y la variación de la tasa de acumulación másica $\left(0.04-0.23 \mathrm{~g} \mathrm{~cm}^{-2}\right.$ año-1) y la tasa de acumulación sedimentaria $\left(0.06-0.61 \mathrm{~cm}^{2}\right.$ año $\left.{ }^{-1}\right)$ se presentan en la fig. 2c.

Validación con ${ }^{137} \mathrm{Cs}$ y ${ }^{239,240} \mathrm{Pu}$

Las actividades de ${ }^{137} \mathrm{Cs}$ y ${ }^{239,240} \mathrm{Pu}$ en los sedimentos del núcleo Alvarado variaron de 1.2 a $4.6 \mathrm{~Bq} \mathrm{~kg}^{-1}$ y de 72 a $182 \mathrm{mBq} \mathrm{kg}{ }^{-1}$, respectivamente. Los perfiles de actividad de ${ }^{137} \mathrm{Cs}$ y ${ }^{239,240} \mathrm{Pu}$ (fig. 2 b) muestran los valores máximos en la sección 11-12 cm que, de acuerdo con el modelo de edad, corresponde a los años entre 1958 y 1966, en perfecto acuerdo con el máximo esperado en 1963.

\section{Caracterización de los sedimentos}

Los sedimentos del núcleo Alvarado fueron predominantemente limosos (69-90\%) y presentaron bajo contenido de materia orgánica $(<2 \%)$ y de carbonatos $(1-7 \%)$. La mayoría de las variables analizadas mostraron escasa variación respecto a la profundidad (fig. 3, notar la reducida amplitud de las escalas), aunque la densidad in situ ( $\rho$ ) de los sedimentos, el contenido de arenas y los valores de susceptibilidad magnética fueron ligeramente más bajos en el segmento inferior (debajo de $26 \mathrm{~cm}$ de profundidad) que hacia la superficie.

Las concentraciones de carbonatos y de Ca presentaron una tendencia constante a disminuir desde el fondo del núcleo hacia la superficie. Los valores de susceptibilidad magnética mostraron un máximo entre 19 y $28 \mathrm{~cm}$ de profundidad (más antiguo que AD $1878 \pm 17$ ), que coincidió con los porcentajes máximos de arena, $\mathrm{Ca}$ y $\mathrm{Zr}$, y los porcentajes mínimos de limo y Rb. Las concentraciones de Al, K, Rb, Si y Fe presentaron una tendencia a disminuir hacia la superficie del núcleo (la tendencia comienza a observarse desde hace más de un siglo, i.e., secciones de antigüedad mayor que $134 \pm 17$ años). Se encontró una correlación positiva $(P<0.001)$ entre el porcentaje de arcillas y las concentraciones de $\mathrm{Al}, \mathrm{Fe}, \mathrm{K}, \mathrm{Rb}$, lo cual sugiere una misma fuente detrítica para los cuatro elementos y su transporte preferencial en la fracción más fina de los sedimentos. En contraste, el porcentaje de arenas presentó una correlación positiva significativa $(P<0.001)$ con la concentración de $\mathrm{Zr}$ y los 

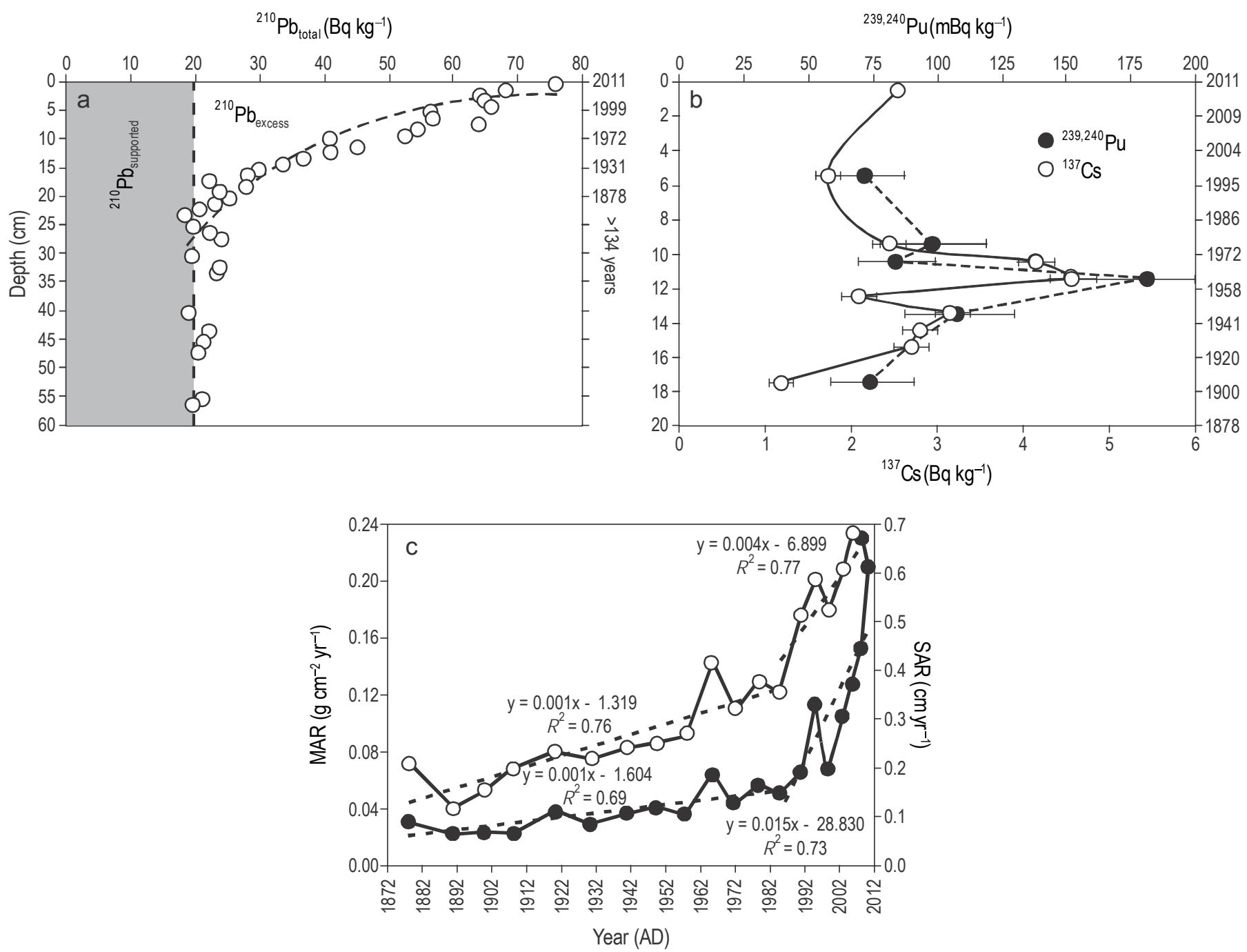

Figure 2. Sediment depth profiles of (a) ${ }^{210} \mathrm{~Pb}$ and (b) ${ }^{137} \mathrm{Cs}$ and ${ }^{239,240} \mathrm{Pu}$. (c) Chronology of the changes in mass accumulation rate (MAR) and sediment accumulation rate (SAR).

Figura 2. Perfiles de actividad de (a) ${ }^{210} \mathrm{~Pb}$ y (b) ${ }^{137} \mathrm{Cs}$ y ${ }^{239,240} \mathrm{Pu}$ respecto a la profundidad. (c) Cronología de los cambios en la tasa de acumulación másica (MAR) y la tasa de acumulación sedimentaria (SAR).

towards the surface of the core (this tendency started more than a century ago, i.e., sections older than $134 \pm 17$ years). A positive correlation $(P<0.001)$ was observed between the percentage of clay and the concentrations of $\mathrm{Al}, \mathrm{Fe}, \mathrm{K}$, and $\mathrm{Rb}$, which suggests that the four elements have the same detritic source and that they are preferentially transported with the finest sediment fraction. In contrast, the percentage of sand showed a significant positive correlation $(P<0.001)$ between the concentration of $\mathrm{Zr}$ and the magnetic susceptibility values, which indicates the possibility of a change in sediment source, with higher concentrations of $\mathrm{Zr}$, found in the coarser sediment fraction (although not very abundant).

To assess whether there were changes in the origin of the accumulated sediments, we calculated the ratios of terrigenous elements ( $\mathrm{Ti} / \mathrm{Al}, \mathrm{Si} / \mathrm{Al}, \mathrm{Zr} / \mathrm{Al}, \mathrm{K} /(\mathrm{Fe}+\mathrm{Mg})$ ) (Sageman and Lyons 2004) and the following chemical weathering indices: terrigenous index $(\mathrm{TI}=\mathrm{Al} /(\mathrm{Al}+\mathrm{Fe}+\mathrm{Mn}$; Boström valores de susceptibilidad magnética, lo cual indica la posibilidad de un cambio de fuente de sedimentos, con mayor contenido de $\mathrm{Zr}$, presente en la fracción más gruesa (aunque poco abundante) del sedimento.

Para evaluar si existieron cambios en el origen de los sedimentos acumulados, se calcularon las razones de elementos indicadores de terrígenos (Ti/Al, Si/Al, $\mathrm{Zr} / \mathrm{Al}$, $\mathrm{K} /(\mathrm{Fe}+\mathrm{Mg})$ ) (Sageman y Lyons 2004) y los siguientes índices de intemperismo químico: índice de terrígenos $(\mathrm{IT}=\mathrm{Al} /(\mathrm{Al}+\mathrm{Fe}+\mathrm{Mn}$; Boström 1973), razón de Ruxton $\left(\mathrm{R}=\mathrm{SiO}_{2} / \mathrm{Al}_{2} \mathrm{O}_{3}\right)$, índice de intemperismo de Parker $\left(\mathrm{WIP}=(100)\left[\left(2 \mathrm{Na}_{2} \mathrm{O} / 0.35\right)+(\mathrm{MgO} / 0.9)+\left(2 \mathrm{~K}_{2} \mathrm{O} / 0.25\right)+\right.\right.$ $(\mathrm{CaO} / 0.7)])$ e índice Si-Ti $\left(\mathrm{STI}=(100)\left[\left(\mathrm{SiO}_{2} / \mathrm{TiO}_{2}\right) /\left(\left(\mathrm{SiO}_{2} /\right.\right.\right.\right.$ $\left.\left.\left.\mathrm{TiO}_{2}\right)+\left(\mathrm{SiO}_{2} / \mathrm{Al}_{2} \mathrm{O}_{3}\right)+\left(\mathrm{Al}_{2} \mathrm{O}_{3} / \mathrm{TiO}_{2}\right)\right)\right]$ ) (Price y Velbel 2003).

Una reducción en los valores de la razón $\mathrm{Si} / \mathrm{Al}$ (déficit de $\mathrm{Si}$ respecto a $\mathrm{Al}$ ) en los sedimentos es indicativo del intemperismo químico de los silicatos, lo cual usualmente 

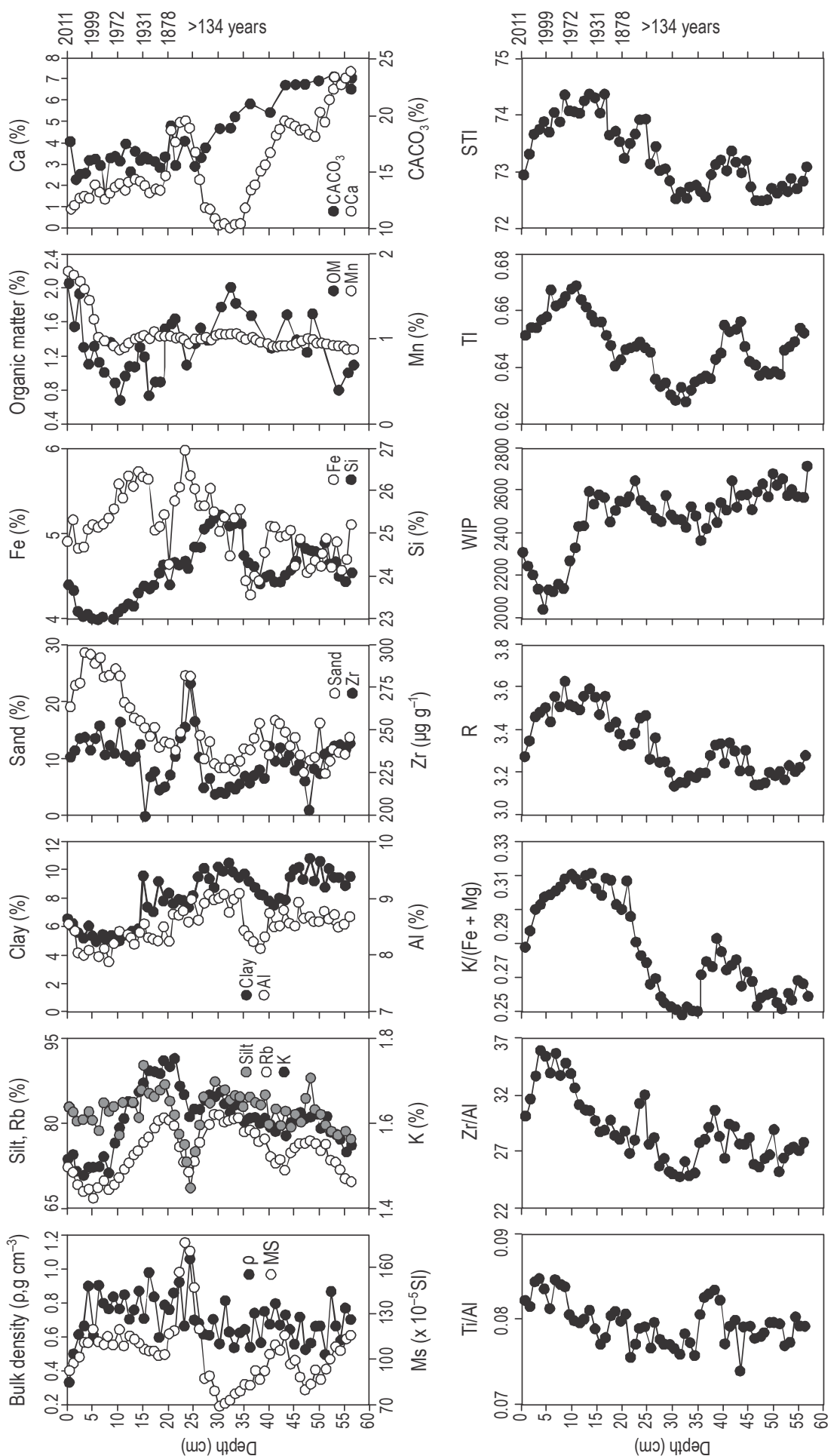

Figure 3. Depth profile and chronology of (upper row) sediment elemental composition and (lower row) ratios of terrigenous elements ( $\mathrm{Ti} / \mathrm{Al}, \mathrm{Zr} / \mathrm{Al}, \mathrm{K} /(\mathrm{Fe}+\mathrm{Mg})$ ) and chemical weathering indices: terrigenous index (TI), Ruxton index (R), weathering index of Parker (WIP), and $\mathrm{Si}-\mathrm{Ti}$ index (STI).

Figura 3. Perfiles respecto a la profundidad y cronología de (fila superior) la composición elemental de los sedimentos y (fila inferior) de las razones de elementos indicadores de terrígenos ( $\mathrm{Ti} / \mathrm{Al}, \mathrm{Zr} / \mathrm{Al}, \mathrm{K} /(\mathrm{Fe}+\mathrm{Mg})$ ) y los índices de intemperismo químico: índice de terrígenos (TI), razón de Ruxton (R), índice de intemperismo de Parker (WIP) e índice Si-Ti (STI). 
1973), Ruxton ratio $\left(\mathrm{R}=\mathrm{SiO}_{2} / \mathrm{Al}_{2} \mathrm{O}_{3}\right)$, weathering index of Parker $\left(\mathrm{WIP}=(100)\left[\left(2 \mathrm{Na}_{2} \mathrm{O} / 0.35\right)+(\mathrm{MgO} / 0.9)+\left(2 \mathrm{~K}_{2} \mathrm{O} /\right.\right.\right.$ $0.25)+(\mathrm{CaO} / 0.7)])$, and $\mathrm{Si}-\mathrm{Ti}$ index $\left(\mathrm{STI}=(100)\left[\left(\mathrm{SiO}_{2} /\right.\right.\right.$ $\left.\left.\left.\mathrm{TiO}_{2}\right) /\left(\left(\mathrm{SiO}_{2} / \mathrm{TiO}_{2}\right)+\left(\mathrm{SiO}_{2} / \mathrm{Al}_{2} \mathrm{O}_{3}\right)+\left(\mathrm{Al}_{2} \mathrm{O}_{3} / \mathrm{TiO}_{2}\right)\right)\right]\right)$ (Price and Velbel 2003).

A decrease in the values of the $\mathrm{Si} / \mathrm{Al}$ ratio (deficit of $\mathrm{Si}$ relative to $\mathrm{Al}$ ) is indicative of the chemical weathering of silicates, which usually produces the preferential dissolution of $\mathrm{Si}$ and $\mathrm{K}$ with respect to $\mathrm{Al}$ in the solid phase (Lopez et al. 2006). In turn, an increase in the $\mathrm{Si} / \mathrm{Al}$ values (excess of $\mathrm{Si}$ relative to $\mathrm{Al}$ ) can indicate an aeolian input of quartz grains, or of biogenic silica (Sageman and Lyons 2004 and references therein). The $\mathrm{Si} / \mathrm{Al}, \mathrm{Ti} / \mathrm{Al}$, and $\mathrm{Zr} / \mathrm{Al}$ ratios in aeolian sediments increase due to the enrichment of quartz, Ti-rich minerals, and zircon (Schnetger et al. 2000 and references therein). Moreover, an increase in the $\mathrm{Si} / \mathrm{Al}$ ratio can reflect more arid conditions or a decrease in fluvial sediment supply in relation to a constant basal aeolian flux (Werne et al. 2002). A decrease in the $\mathrm{K} /(\mathrm{Fe}+\mathrm{Mg})$ values indicates an increase in the fluvial supply of detrital clastic sediments (Sageman and Lyons 2004).

The terrigenous index is used to identify the terrigenous input to the sediment, the values decreasing with increasing distance from the continent (Böstrom 1973). The other three chemical weathering indices decrease with weathering (Price and Velbel 2003). The Ruxton index is based on the loss of Si and assumes that $\mathrm{Al}$ is immobile during weathering. The weathering index of Parker is based on the ratios of alkali metals to alkaline earth metals $(\mathrm{Na}, \mathrm{K}, \mathrm{Mg}$, and $\mathrm{Ca}$, the most mobile elements) during silicate weathering. The Si-Ti index evaluates the degree of chemical weathering of silicate metamorphic rocks in tropical regions.

There was a first maximum in the $\mathrm{Ti} / \mathrm{Al}, \mathrm{Zr} / \mathrm{Al}$, and $\mathrm{K} /(\mathrm{Fe}+\mathrm{Mg})$ ratios and the Ruxton, terrigenous, and $\mathrm{Si}-\mathrm{Ti}$ indices between 35 and $45 \mathrm{~cm}$ depth (older than AD $1878 \pm$ 17 , maximum age of this study), accompanied by an increase in the percentages of sand and $\mathrm{Zr}$ (fig. 3), which indicates an increased input of detritic material. According to the terrigenous and $\mathrm{Si}-\mathrm{Ti}$ indices, these sediments are less weathered than the older sediments found below $45 \mathrm{~cm}$ depth and could be, for instance, coastal sediments transported by a catastrophic event (e.g., a storm or hurricane). More recently, the $\mathrm{Ti} / \mathrm{Al}, \mathrm{Zr} / \mathrm{Al}$, and $\mathrm{K} /(\mathrm{Fe}+\mathrm{Mg})$ ratios and the four weathering indices showed a tendency to increase towards the $10-11 \mathrm{~cm}$ depth section (AD $1966 \pm 3$ ), indicating an increase in the transport of slightly weathered continental sediments, probably due to the gradual increase in erosion rate and transport of near-shore sediments.

The highest values of the Ti/Al and $\mathrm{Zr} / \mathrm{Al}$ ratios occurred between 10 and $3 \mathrm{~cm}$ depth (1972-2004). On the other hand, the $\mathrm{K} /(\mathrm{Fe}+\mathrm{Mg})$ ratio and the Ruxton, terrigenous, and $\mathrm{Si}-\mathrm{Ti}$ indices started to decrease gradually towards the surface. This indicates a decrease in the fluvial input of detrital material (shown by $\mathrm{K} /(\mathrm{Fe}+\mathrm{Mg})$ ), as well as an increase in more weathered material (Ruxton and Si-Ti indices) that originates produce la disolución preferente de $\mathrm{Si}$ y $\mathrm{K}$ respecto a $\mathrm{Al}$ en la fase sólida (Lopez et al. 2006). En cambio, el incremento de la razón $\mathrm{Si} / \mathrm{Al}$ (exceso de $\mathrm{Si}$ respecto a $\mathrm{Al}$ ) puede indicar el suministro de granos de cuarzo vía eólica, o bien de sílice biogénica (Sageman y Lyons 2004 y referencias en el mismo). Las razones $\mathrm{Si} / \mathrm{Al}, \mathrm{Ti} / \mathrm{Al}$ y $\mathrm{Zr} / \mathrm{Al}$ aumentan en los sedimentos eólicos debido al enriquecimiento de cuarzo, minerales ricos en Ti y circón (Schnetger et al. 2000 y referencias en el mismo). Asimismo, el incremento en la razón $\mathrm{Si} / \mathrm{Al}$ puede reflejar condiciones más áridas o un decremento en el suministro fluvial de sedimentos con relación a un flujo basal eólico constante (Werne et al. 2002). Un aumento en los valores de $\mathrm{K} /(\mathrm{Fe}+\mathrm{Mg})$ indica el incremento en el aporte fluvial de sedimentos clásticos detríticos (Sageman y Lyons 2004).

El IT es utilizado para identificar el suministro de terrígenos a los sedimentos y sus valores disminuyen con la distancia al continente (Böstrom 1973). Los valores de R, WIP y STI decrecen con el intemperismo (Price y Velbel 2003). El índice R está basado en la pérdida de Si y asume la inmovilidad de Al durante el intemperismo. El WIP está basado en las proporciones de metales alcalinos y alcalino térreos $(\mathrm{Na}, \mathrm{K}, \mathrm{Mg}$ y $\mathrm{Ca}$, los elementos mayoritarios más móviles) durante el intemperismo de los silicatos. El STI evalúa el grado de intemperismo químico de rocas metamórficas silicatadas en regiones tropicales.

Se observó un primer máximo en las razones Ti/Al, $\mathrm{Zr} / \mathrm{Al}$ y K/(Fe $+\mathrm{Mg}$ ) y los valores de R, IT y STI entre 35 y $45 \mathrm{~cm}$ de profundidad (más antiguos que $\mathrm{AD} 1878 \pm 17$, límite de fechado de este estudio), acompañados por un incremento en el porcentaje de arenas y de $\mathrm{Zr}$ (fig. 3), que indica un incremento en el aporte de material detrítico. De acuerdo a los valores de IT y STI, se trata de sedimentos menos intemperizados que los sedimentos más antiguos encontrados por debajo de $45 \mathrm{~cm}$ de profundidad, y podrían ser, por ejemplo, sedimentos litorales acarreados por un evento catastrófico (e.g., una tormenta o huracán). Para los sedimentos más recientes, las razones $\mathrm{Ti} / \mathrm{Al}, \mathrm{Zr} / \mathrm{Al}, \mathrm{K} /(\mathrm{Fe}+\mathrm{Mg})$ y los valores de R, WIP, IT y STI mostraron una tendencia a incrementarse hasta la sección de 10-11 cm de profundidad (AD $1966 \pm 3$ ) lo cual indica el incremento del transporte de sedimentos continentales poco intemperizados, probablemente debido al gradual incremento de la erosión y transporte de sedimentos próximos a la costa.

Entre 10 y $3 \mathrm{~cm}$ de profundidad (1972-2004), las razones $\mathrm{Ti} / \mathrm{Al}$ y $\mathrm{Zr} / \mathrm{Al}$ se mantuvieron en sus valores máximos, pero los valores de la razón $\mathrm{K} /(\mathrm{Fe}+\mathrm{Mg})$ y de R, IT, STI comenzaron a disminuir gradualmente hacia la superficie. Esto indica un decremento en el aporte de material detrítico fluvial (indicado por $\mathrm{K} /(\mathrm{Fe}+\mathrm{Mg}))$, así como el aumento de material más intemperizado (R y STI) que procede desde cada vez mayor distancia en el continente (índice IT) y que es transportado principalmente por vía eólica (razón Ti/Al). Aunque el índice WIP no muestra la misma tendencia decreciente que R y STI (de hecho muestra una tendencia creciente en los $5 \mathrm{~cm}$ 
at a greater distance from the continent (terrigenous index) and that is primarily transported by the wind ( $\mathrm{Ti} / \mathrm{Al}$ ratio). The weathering index of Parker does not show the same decreasing trend as the Ruxton and Si-Ti indices and in fact shows an increasing trend in the uppermost $5 \mathrm{~cm}$, but this section includes the lowest values of this index.

\section{DisCUSSION}

The activities of ${ }^{137} \mathrm{Cs}$ are low but consistent with values reported for other areas of the Pacific coast of Mexico (PáezOsuna and Mandelli 1985; Ruiz-Fernández et al. 2001, 2004, 2007) and with those reported for the Coatzacoalcos River estuary, about $250 \mathrm{~km}$ to the south of the Alvarado Lagoon (Rosales-Hoz et al. 2003, Ruiz-Fernández et al. 2012). The low ${ }^{137} \mathrm{Cs}$ activities, common in subtropical and tropical areas, can be attributed mainly to three factors: (a) elapsed time since its release to the environment, as current ${ }^{137} \mathrm{Cs}$ activities, accumulated in sediments since the mid-1960s, have decreased by circa $70 \%$ due to radioactive decay; (b) geographical location, because only about $9 \%$ of the total amount of ${ }^{137} \mathrm{Cs}$ released into the atmosphere is deposited at latitudes $10-20^{\circ} \mathrm{N}$ (Aoyama et al. 2006); and (c) geochemical behavior, because ${ }^{137} \mathrm{Cs}$ can be mobilized from sediments due to its high solubility in seawater or as a result of anoxic and highly reducing conditions (IAEA 2005).

The activities of ${ }^{239,240} \mathrm{Pu}$ are also low and consistent with values documented for the Coatzacoalcos River estuary $\left(0.06 \pm 0.01\right.$ to $0.19 \pm 0.01 \mathrm{~Bq} \mathrm{~kg}^{-1}$, Ruiz-Fernández et al. 2012). Few data are available for tropical latitudes of the American Atlantic coast, but the ${ }^{239,240} \mathrm{Pu}$ values obtained for the Alvarado sediments are similar to those reported for an intertidal marsh on the southeast coast of Brazil $\left(<0.02-0.19 \mathrm{~Bq} \mathrm{~kg}^{-1}\right.$, Sanders et al. 2010) and for Cuban coastal areas $\left(0.01-0.78 \mathrm{~Bq} \mathrm{~kg}^{-1}\right.$, Corcho-Alvarado et al. 2014).

The mass accumulation rate $\left(0.04-0.23 \mathrm{~g} \mathrm{~cm}^{-2} \mathrm{yr}^{-1}\right)$ and sediment accumulation rate $\left(0.09-0.61 \mathrm{~cm} \mathrm{yr}^{-1}\right)$ have increased consistently over the past $134 \pm 17$ years (fig. 2c), equivalent to an increase in sediment accumulation rate of about $670 \%$ between 1878 and 2011 and of about $470 \%$ between 1972 and 2011. The acceleration in sediment accumulation during the most recent period $\left(0.015 \mathrm{~cm} \mathrm{yr}^{-2}\right.$, 1986-2011) is one order of magnitude greater than that observed between the late 19th century and the early 1980s $\left(0.001 \mathrm{~cm} \mathrm{yr}^{-2}\right)$.

The $\mathrm{Ti} / \mathrm{Al}, \mathrm{Zr} / \mathrm{Al}$, and $\mathrm{K} /(\mathrm{Fe}+\mathrm{Mg})$ ratios and the terrigenous index, Ruxton index, weathering index of Parker, and $\mathrm{Si}-\mathrm{Ti}$ index indicated the incorporation of eroded sediments from the contiguous basin during more than one century, although during the past $39 \pm 2$ years the sediments originate from increasingly distant sources. According to previous reports for the area (DOF 2004), human activities are primarily responsible for the erosion problems impacting Alvarado Lagoon. superficiales), esta sección incluye los valores más bajos de WIP en todo el perfil.

\section{DISCUSIÓN}

Las actividades de ${ }^{137} \mathrm{Cs}$ son bajas pero consistentes con los valores previamente registrados en otras áreas costeras mexicanas del Pacífico (Páez-Osuna y Mandelli 1985; RuizFernández et al. 2001, 2004, 2007) y con los observados en el estuario del río Coatzacoalcos, a $\sim 250 \mathrm{~km}$ al sur de la laguna de Alvarado (Rosales-Hoz et al. 2003, Ruiz-Fernández et al. 2012). Las bajas actividades de ${ }^{137} \mathrm{Cs}$, comunes en áreas costeras subtropicales y tropicales, pueden deberse principalmente a tres factores: (a) tiempo transcurrido desde su liberación al ambiente, ya que debido a la desintegración radioactiva, las actividades de ${ }^{137} \mathrm{Cs}$, acumuladas en el sedimento desde mediados de 1960, a la fecha han disminuido alrededor de un $70 \%$; (b) ubicación geográfica, ya que se estima que de la cantidad total de ${ }^{137} \mathrm{Cs}$ liberada a la atmósfera, tan sólo un $9 \%$ se depositó en las latitudes $10-20^{\circ} \mathrm{N}$ (Aoyama et al. 2006); y (c) comportamiento geoquímico, ya que el ${ }^{137} \mathrm{Cs}$ puede ser movilizado de los sedimentos, ya sea debido a su alta solubilidad en agua de mar, o a consecuencia de condiciones anóxicas y altamente reductoras (IAEA 2005).

Las actividades de ${ }^{239,240} \mathrm{Pu}$ también son bajas y consistentes con los valores registrados para el estuario del río Coatzacoalcos $\left(0.06 \pm 0.01\right.$ a $0.19 \pm 0.01 \mathrm{~Bq} \mathrm{~kg}{ }^{-1}$, RuizFernández et al. 2012). En comparación con los escasos datos disponibles en latitudes tropicales de la costa atlántica americana, los valores de ${ }^{239,240} \mathrm{Pu}$ en los sedimentos de Alvarado son comparables a los encontrados por en una marisma intermareal de la costa sureste de Brasil $\left(<0.02-0.19 \mathrm{~Bq} \mathrm{~kg}^{-1}\right.$, Sanders et al. 2010) y en zonas costeras de Cuba (0.01-0.78 Bq kg-1, Corcho-Alvarado et al. 2014).

Las tasas de acumulación másica $\left(0.04-0.23 \mathrm{~g} \mathrm{~cm}^{-2}\right.$ año $\left.^{-1}\right)$ y de acumulación sedimentaria $\left(0.09-0.61 \mathrm{~cm}^{2}\right.$ año $\left.{ }^{-1}\right)$ incrementaron de manera consistente a lo largo de los últimos $134 \pm 17$ años (fig. 2c), equivalente a un aumento de alrededor del $670 \%$ en las tasas de acumulación sedimentaria entre 1878 y 2011, y de al rededor del $470 \%$ entre 1972 y 2011. Es notable que la aceleración de la acumulación de sedimento durante el periodo más reciente $\left(0.015 \mathrm{~cm}\right.$ año ${ }^{-2}$, 1986-2011) es un orden de magnitud mayor que el observado entre fines del siglo XIX y principios de la década de 1980 $(0.001 \mathrm{~cm}$ año-2) .

De acuerdo con las razones de elementos mayoritarios (Ti/Al, $\mathrm{Zr} / \mathrm{Al}$ y $\mathrm{K} /(\mathrm{Fe}+\mathrm{Mg})$ ) y los índices de intemperismo $\mathrm{R}$, WIP, IT y STI, hace más de un siglo que la incorporación de sedimentos erosionados proviene de la cuenca próxima, aunque durante los últimos $39 \pm 2$ años los sedimentos proceden de fuentes cada vez más lejanas. Según los registros previos para la zona (DOF 2004), la influencia humana es el factor más importante en los problemas de erosión que impactan a la laguna de Alvarado. 
Deforestation and changes in land use and vegetation cover in Mexico are problems that have existed since preColumbian times and have increased dramatically over the past four decades. Deforestation rates in the country vary between 370 and 746 thousand hectares per year for rainforests and closed forests (Aguilar et al. 2000 and references therein). The area occupied by the municipality of Alvarado has been inhabited by diverse indigenous groups since before the arrival of the Spaniards, and there are records of agricultural activities related to the cultivation and production of sugarcane since the mid-16th century (SEGOB 2010) that may have contributed to the erosion of the land in the vicinity of the Alvarado Lagoon System.

The considerable increase in sediment accumulation recorded in the Alvarado core since the 1980s (fig. 2c) can only be attributed to changes in land use and inadequate agricultural practices that accelerate soil erosion in the drainage basin. According to Bello et al. (2009), the Alvarado Lagoon System has high deforestation rates: between 1976 and 2000, nearly 7000 ha of wetland vegetation and more than 3000 ha of dunes (i.e., $22 \%$ and $98 \%$, respectively) were lost in the vicinity of the Alvarado Lagoon mouth. These changes are attributed to the increase in livestock farming and the transforming of areas of natural vegetation into pastures (91\% of the seasonal agricultural areas in 1976 were converted to grassland), as well as to the expansion of sugarcane cultivation (Pronatura 2014). Also between 1976 and 2000, the annual deforestation rate in the highland rainforests was $12 \%$. This high deforestation in the more elevated areas of the basin has caused soil erosion and, consequently, siltation at the mouth of Alvarado Lagoon (Bello et al. 2009).

Dated sediment cores are unique records of local, regional, and global processes. While the results of this study may not be easily extrapolated to the rest of the lagoon system, the sedimentary record reflects a regional process: the erosion of the catchment basin of the Alvarado Lagoon System. This work offers a first quantitative reconstruction of the siltation history of the Alvarado Lagoon and constitutes a reliable basis for future studies that will lead to better management of the coastal area.

\section{ACKNOWLEDGMENTS}

This study was funded through projects PAPIIT-DGAPA IN105009, PAPIIT-DGAPA IN203313, INFR-2013-01 204818, and Red PROMEP/103.5/13/9366. PLM received a scholarship from the National Council for Science and Technology (CONACYT, Mexico). The authors acknowledge the help provided by Rosalba Alonso Rodríguez (field work), Humberto Bojórquez (laboratory work), and Germán Ramírez and Carlos Suárez (figures), and thank the two anonymous reviewers for their valuable comments.

English translation by Christine Harris.
La deforestación y el cambio en la cobertura y uso del suelo en México son un problema que se ha presentado desde tiempos precolombinos; además, durante las últimas cuatro décadas, este proceso se ha incrementado dramáticamente, pues se estima que las tasas de deforestación en el país varían entre 370-746 mil ha año-1 para selvas y bosques cerrados (Aguilar et al. $2000 \mathrm{y}$ referencias incluidas). La zona que hoy ocupa el municipio de Alvarado había estado habitada por diversos grupos indígenas antes de la llegada de los españoles, y se reporta que desde mediados del siglo XVI existían actividades agrícolas, relacionadas con el cultivo de caña y producción de azúcar (SEGOB 2010), que podrían haber contribuido a la erosión de los terrenos en los alrededores del complejo lagunar de Alvarado.

El incremento considerable de la acumulación sedimentaria registrado en el núcleo Alvarado a partir de la década de 1980 (fig. 2c) tan sólo puede ser atribuido a cambios de uso del suelo y prácticas inadecuadas de cultivo agrícola, que aceleran la erosión de suelos en la cuenca de drenaje. De acuerdo con Bello et al. (2009), el complejo lagunar de Alvarado tiene altas tasas de deforestación: entre 1976 y 2000, en los alrededores de la boca de la laguna de Alvarado se perdieron cerca de 7000 ha de vegetación característica de humedales y más de 3000 ha de dunas (i.e., el 22\% y 98\%, respectivamente). Estos cambios son atribuidos al incremento de la ganadería, dada la transformación de vegetación natural a zonas de pastizales inducidos $(91 \%$ de las zonas de agricultura temporal de 1976 fue convertido a pastizales), así como a la expansión de terrenos de cultivos de caña de azúcar (Pronatura 2014). En el mismo periodo (1976-2000), la tasa de deforestación en las selvas altas de la zona fue del $12 \%$ anual. Las altas tasas de deforestación desde las zonas altas de la cuenca han sido relacionadas con la erosión de suelos, que han tenido como consecuencia el azolvamiento de la boca de la laguna de Alvarado (Bello et al. 2009).

Los núcleos sedimentarios fechables son registros únicos de procesos locales, regionales y globales. Si bien los resultados de este estudio no pueden ser fácilmente extrapolados al resto del complejo lagunar, el registro sedimentario refleja un proceso regional: la erosión de la cuenca de captación del complejo lagunar de Alvarado. Este estudio es la primera reconstrucción cuantitativa de la historia del azolvamiento de la laguna de Alvarado y, por lo tanto, constituye una base confiable para futuros estudios que permitan una mejor gestión de la zona costera.

\section{Agradecimientos}

Este trabajo fue posible gracias al financiamiento de los proyectos PAPIIT-DGAPA IN105009, PAPIIT-DGAPA IN203313, INFR-2013-01 204818 y Red PROMEP/103.5/ 13/9366; y a la beca de maestría de CONACYT otorgada a PLM. Los autores agradecemos el apoyo de Rosalba Alonso Rodríguez en el trabajo de campo, el apoyo técnico 


\section{REFERENCES}

Aguilar C, Martínez E, Arriaga L. 2000. Deforestación y fragmentación de ecosistemas: Qué tan grave es el problema en México? Biodiversitas 30: 7-11.

Aoyama A, Hirose K, Igarashi Y. 2006. Re-construction and updating our understanding on the global weapons tests ${ }^{137} \mathrm{Cs}$ fallout. J. Environ. Monitor. 8: 431-438.

Arriaga L, Espinoza JM, Aguilar C, Martínez E, Gómez L, Loa E. (coordinadorescoordinators/eds.). 2000. Regiones terrestres prioritarias de México. Comisión Nacional para el Conocimiento y Uso de la Biodiversidad, México. http://www.conabio.gob.mx/conocimiento/regionalizacion/

Bello J et al., Gómez L, et al., Magaña V et al., Graizbord B et al., Rodríguez PH et al. 2009. Sitio piloto Río Papaloapan-Laguna de Alvarado. In: Buenfil Friedman J (ed.), Adaptación a los Impactos del Cambio Climático en los Humedales Costeros del Golfo de México. Vol. II. Secretaría de Medio Ambiente y Recursos Naturales/Instituto Nacional de Ecología, México, pp. 435-456.

Boström K. 1973. The origin and fate of ferromanganoan active ridge sediments. Stockholm Contrib. Geol. 27: 149-243.

[CONANP] Comisión Nacional de Áreas Naturales protegidas. 2014. Humedales mexicanos de importancia internacional (sitios RAMSAR). http://ramsar.conanp.gob.mx/docs/sitios/ FIR_RAMSAR/Veracruz

Contreras-Espinosa F. 1993. Ecosistemas costeros mexicanos. Universidad Autónoma Metropolitana. México, 415 pp.

Corcho-Alvarado JA, Díaz-Asencio M, Froidevaux P, Bochud F, Alonso-Hernández CM, Sanchez-Cabeza JA. 2014. Dating young Holocene coastal sediments in tropical regions: Use of fallout ${ }^{239,240} \mathrm{Pu}$ as alternative chronostratigraphic marker. Quatern. Geochronol. 22: 1-10.

DeLaune RD, Patrick Jr WH, Buresh RJ. 1978. Sedimentation rates determined by ${ }^{137} \mathrm{Cs}$ dating in a rapidly accreting salt marsh. Nature 275: 532-533.

[DOF] Diario Oficial de la Federación. 2004. Carta Nacional Pesquera. Ecosistemas lagunares costeros. Laguna Alvarado, Veracruz. DOF, quinta sección, 15 mayo 2004, México.

Guzmán-Amaya P, Villanueva FS, Botello AV. 2005. Metales en tres lagunas costeras del estado de Veracruz. In: Botello AV, Rendón-von-Osten J, Gold-Bouchot G, Agraz-Hernández C (eds.), Golfo de México, Contaminación e Impacto Ambiental: Diagnóstico y Tendencias. 2nd ed. Universidad Autónoma de Campeche, Universidad Nacional Autónoma de México, Instituto Nacional de Ecología, pp. 361-372.

[IAEA] International Atomic Energy Agency. 2005. Worldwide marine radioactivity studies (WOMARS). Radionuclide levels in oceans and seas. Final report of a coordinated research project. IAEA-TECDOC-1429, $187 \mathrm{pp}$.

[INEGI] Instituto Nacional de Estadística y Geografía. 2009. Prontuario de información geográfica municipal de los Estados Unidos Mexicanos. Alvarado, Veracruz de Ignacio de la Llave. http://www3.inegi.org.mx/sistemas/mexicocifras/datosgeograficos/30/30011.pdf

Koinig KA, Shotyk W, Lotter AF, Ohlendorf C, Sturm M. 2003. 9000 years of geochemical evolution of lithogenic major and trace elements in the sediment of an alpine lake: The role of climate, vegetation, and land-use history. J. Paleolimnol. 30: 307-320.

Lopez P, Navarro E, Marce R, Ordoñez J, Caputo L, Armengol J. 2006. Elemental ratios in sediments as indicators of ecological processes in Spanish reservoirs. Limnetica 25: 499-512.

Loring DH, Rantala RTT. 1992. Geochemical analyses of marine sediments and suspended particulate matter. Fisheries and Marine Services, Technical Report 700, p. 58. de Humberto Bojórquez en el trabajo de laboratorio y de Germán Ramírez y Carlos Suárez en la elaboración de figuras, así como los valiosos comentarios de dos revisores anónimos de la primera versión del manuscrito.

Nicholls RJ, Small C. 2002. Improved estimates of coastal population and exposure to hazards released. EOS 83: 301-305.

Páez-Osuna F, Mandelli EF. $1985 .{ }^{210} \mathrm{~Pb}$ in a tropical coastal lagoon sediment core. Estuar. Coast. Shelf Sci. 20: 374-387.

Portilla-Ochoa. 2003. Ficha Informativa de los Humedales de Ramsar del Sistema Lagunar Alvarado. http:// ramsar.conanp.gob.mx/docs/sitios/FIR_RAMSAR/Veracruz

Price JR, Velbel MA. 2003. Chemical weathering indices applied to weathering profiles developed on heterogeneous felsic metamorphic parent rocks. Chem. Geol. 202: 397-416.

Pronatura. 2014. Manglares. Pronatura Veracruz, AC. http:// www.pronaturaveracruz.org/ecoforestal/ef_manglares.php

Puphal KW, Olsen DR. 1972. Electrodeposition of alpha-emitting nuclides from a mixed oxalate-chloride electrolyte. Anal. Chem. 44: 284-289.

Robbins JA. 1978. Geochemical and geophysical applications of radioactive lead isotopes. In: Nriagu JP (ed.), Biogeochemistry of Lead. Elsevier Science BV, Amsterdam, pp. 285-393.

Rosales HL, Carranza EA, Alvarez RU. 1986. Sedimentological and chemical studies in sediments from Alvarado lagoon system, Veracruz, Mexico. An. Inst. Cienc. Mar Limnol. UNAM 13: 19-28.

Rosales-Hoz L, Cundy AB, Bahena-Manjarrez JL. 2003. Heavy metals in sediment cores from a tropical estuary affected by anthropogenic discharges, Coatzacoalcos Estuary, Mexico. Estuar. Coast. Shelf Sci. 58, 117-126.

Ruiz-Fernández AC, Hillaire-Marcel C, Ghaleb B, Páez-Osuna F, Soto-Jiménez M. 2001. Isotopic constraints $\left({ }^{210} \mathrm{~Pb},{ }^{228} \mathrm{Th}\right)$ on the sedimentary dynamics of contaminated sediments from a subtropical coastal lagoon (NW Mexico). Environ. Geol. 41: 74-89.

Ruiz-Fernández AC, Páez-Osuna F, Machain-Castillo ML, Arellano-Torres E. 2004. ${ }^{210} \mathrm{~Pb}$ geochronology and trace metal fluxes $(\mathrm{Cd}, \mathrm{Cu}$ and $\mathrm{Pb})$ in the Gulf of Tehuantepec, South Pacific of Mexico. J. Environ. Radioactiv. 76: 161-175.

Ruiz-Fernández A, Frignani $M$, Tesi T, Bojórquez-Leyva $H$, Bellucci L, Páez-Osuna F. 2007. Recent sedimentary history of organic matter and nutrient accumulation in the Ohuira Lagoon, nortwestern Mexico. Arch. Environ. Contam. Toxicol. 53: $159-167$.

Ruiz-Fernández AC, Hillaire-Marcel C, de Vernal A, MachainCastillo ML, Vásquez L, Ghaleb B, Aspiazu-Fabián JA, PáezOsuna F. 2009. Changes of coastal sedimentation in the Gulf of Tehuantepec, South Pacific Mexico, over the last 100 years from short-lived radionuclide measurements. Estuar. Coast. Shelf Sci. 82: 525-536.

Ruiz-Fernández AC, Sanchez-Cabeza JA, Alonso-Hernández C, Martínez-Herrera V, Pérez-Bernal LH, Preda M, Hillaire-Marcel C, Gastaud J, Quejido-Cabezas AJ. 2012. Effects of land use change and sediment mobilization on coastal contamination (Coatzacoalcos River, Mexico). Cont. Shelf Res. 37: 57-65.

Ruiz-Fernández AC, Sanchez-Cabeza JA, Ontiveros Cuadras JF, Páez Osuna F. 2014. Registros ambientales del cambio global. Revista Ciencia y Desarrollo 40: 6-11.

Sageman BB, Lyons TW. 2004. Geochemistry of fine-grained sediments and sedimentary rocks. In: MacKenzie F (ed.), 
Sediments, Diagenesis, and Sedimentary Rocks, Treatise on Geochemistry. Vol. 7. Elsevier, New York, pp. 115-158.

Sanchez-Cabeza JA, Ruiz-Fernández AC. 2012. ${ }^{210} \mathrm{~Pb}$ sediment radiochronology: An integrated formulation and classification of dating models. Geochim. Cosmochim. Acta 82: 183-200.

Sanchez-Cabeza JA, Díaz-Asencio M, Ruiz-Fernández AC (Editors). 2012. Radiocronología de sedimentos costeros utilizando ${ }^{210} \mathrm{~Pb}$ : Modelos, validación y aplicaciones. International Atomic Energy Agency, Vienna, STI/PUB/1538, 2012, 105 pp. http://www-pub.iaea.org/MTCD/Publications/ PDF/P1538_S_web.pdf

Sanchez-Cabeza JA, Ruiz-Fernández AC, Ontiveros Cuadras JF, Pérez Bernal LH. 2014. Monte Carlo uncertainty calculation of ${ }^{210} \mathrm{~Pb}$ sediment dating chronologies and accumulation rates. Quatern. Geochronol. 23: 80-93.

Sanders CJ, Soak JM, Sanders LM, Waters MN, Patchineelam SR, Ketterer ME. 2010. Intertidal mangrove mudflat ${ }^{240+239} \mathrm{Pu}$ signatures, confirming a ${ }^{210} \mathrm{~Pb}$ geochronology on the southeastern coast of Brazil. J Radioanal Nucl Chem 283: 593-596.
Schnetger B, Brumsack HJ, Schale H, Hinrichs J, Dittert L. 2000. Geochemical characteristics of deep-sea sediments from the Arabian Sea: A high-resolution study. Deep-Sea Res (II) 47: 2735-2768.

[SEGOB] Secretaría de Gobernación. 2010. Enciclopedia de los Municipios de México. Municipio de Alvarado. INAFED Instituto para el Federalismo y el Desarrollo Municipal, Secretaría de Gobernación. http://www.e-local.gob.mx/wb2/ ELOCAL/EMM_veracruz.

Stuardo J, Villarroel M. 1976. Aspectos ecológicos y moluscos en las lagunas costeras de Guerrero, México. An. Cent. Cienc. Mar Limnol. UNAM 3: 1-180.

Vitousek PM. 1994. Beyond global warming: Ecology and global change. Ecology 75: 1861-1876.

Werne JP, Sageman BB, Lyons TW, Hollander DJ. 2002. An integrated assessment of a "Type euxinic" deposit: Evidence for multiple controls on black shale deposition in the Middle Devonian Oatka Creek Formation. Am. J. Sci. 302: 110-143.

Wong KM. 1971. Radiochemical determination of plutonium in sea water, sediments and marine organisms. Analytica Chimica Acta 56,3: 355-364.

Received September 2014, accepted December 2014. 